\title{
BIOAKUMULASI LOGAM Pb DAN Cr DALAM SISTEM BIOFILTRASI VERTIKAL DENGAN INOKULUM BAKTERI YANG DIISOLASI DARI BEBERAPA PERAIRAN KAWASAN DENPASAR SELATAN
}

\author{
Dini Imanniar ${ }^{1 *}$, I.W. Budiarsa Suyasa ${ }^{1)}$, I. W. Sudiarta ${ }^{1)}$ \\ 1)Jurusan Kimia FMIPA Universitas Udayana \\ *Email: diniimanniar@yahoo.co.id
}

\begin{abstract}
ABTRACT
Research of bioaccumulation of $\mathrm{Pb}$ and $\mathrm{Cr}$ in vertical biofiltration systems with bacterial inoculum derived from aquatic sediments South Denpasar aims to get the best sediment sources that can be used as an active suspension to process metals $\mathrm{Pb}$ and $\mathrm{Cr}$ dissolved. Sediment samples taken from some waters are ecosystems Mangrove Statue Ngurah Rai Tuban, Benoa Harbour and Estuary Dam Suwung. Each sediment samples were grown in a liquid medium to get the best active suspension, which was determined by an increase in biomass ( VSS ) and the speed of growth. Best active suspension is used as inoculum in the vertical biofilters to decreaseconcentration of $\mathrm{Pb}$ and $\mathrm{Cr}$ dissolved. Ability of vertical biofilter is determined by their effectiveness in lowering levels of $\mathrm{Pb}$ and $\mathrm{Cr}$ and capacity of the system used.

The results showed that the vertical biofiltration system capable of lowering the concentration of $\mathrm{Pb}$ and $\mathrm{Cr}$ to each concentration became $0.1680 \mathrm{ppm}$ and $0.1460 \mathrm{ppm}$ within 6 hours of treatment with initial concentration of 2 ppm respectively. The results showed that the vertical biofiltration system capable of decreasing the concentration of $\mathrm{Pb}$ and $\mathrm{Cr}$ became $0.1680 \mathrm{ppm}$ and $0.1460 \mathrm{ppm}$ within 6 hours of treatment with initial concentration of $2 \mathrm{ppm}$ respectively. This concentration has been below the qualitystandard (PerGub Bali No.8 Tahun 2007). The highest effectiveness of vertical biofilters system against $\mathrm{Pb}$ and $\mathrm{Cr}$ occurred while processing time of 24 hours with the respective value amounted to $99.49 \%$ and $99.41 \%$. While the value of biofiltration capacity in lowering the concentration of $\mathrm{Pb}$ and $\mathrm{Cr}$ amounting $4,3188 \times 10^{-3} \mathrm{mg} / \mathrm{g}$ and $4,5369 \times 10^{-3} \mathrm{mg} / \mathrm{g}$. In microbiological tests, one type of bacteria that play a role in the process of bioaccumulation of $\mathrm{Pb}$ and $\mathrm{Cr}$ is Bacillus sp in the amount of $20 \mathrm{CFU} / \mathrm{g}$.
\end{abstract}

Keywords : Bifiltration, active suspension, effectiveness, capacity

\section{PENDAHULUAN}

Salah satu masalah besar yang banyak dihadapi oleh negara-negara di dunia adalah pencemaran logam berat. Hal ini dikarenakan semakin maraknya penggunaan logam berat di dalam kegiatan industri.Limbah cair yang dihasilkan industri pengguna logam berat merupakan penyumbang utama logam berat di lingkungan. Sifat logam berat yang tidak dapat terdegradasi secara alami seperti layaknya pencemar organik menjadi sumber masalah utama (Hegazi, 2013). Diantara berbagai macam logam berat, $\mathrm{Pb}$ dan $\mathrm{Cr}$ merupakan logam yang menjadi perhatian utama dikarenakan memiliki kegunaan yang besar di negara-negara berkembang (Magni et al., 2015).

Di Bali khususnya kawasan Denpasar Selatan terdapat beberapa perairan yang diindikasi mengandung unsur logam berat di dalamnya, perairan tersebut antara lain perairan Mangrove Patung Ngurah Rai Tuban, Pelabuhan Benoa, dan Estuari Dam Suwung. Fakta ini didukung oleh penelitian (Suriani, 2007) yang mengatakan bahwa pada perairan mangrove Patung Ngurah Rai Tuban Denpasar Selatan mengandung logam berat Kromiun (Cr) sebesar 0,07 ppm, Kadmium (Cd) sebesar 0,025 ppm, Kobalt (Co) sebesar 0,004 ppm, Tembaga (Cu) sebesar 0,009 ppm.
Keberadaan logam $\mathrm{Pb}$ dan $\mathrm{Cr}$ pada perairan Estuari Dam Suwung, Berdasarkan penelitian (Bogoriani, 2007) diketahui bahwa kadar $\mathrm{Pb}$ dan $\mathrm{Cr}$ pada ikan nila rata-rata berkisar 10,1910-10,7710 mg/ $\mathrm{kg}$ berat basah dan 1,3460 2,9642 mg/kg berat basah.

Sedangkan keberadaan logam $\mathrm{Pb}$ dan $\mathrm{Cr}$ pada Pelabuhan Benoa menurut (Dewi et al., 2014) konsentrasi logam $\mathrm{Pb}$ total dalam sedimen yang diayak basah dan kering berturut-turut sebesar $18,4852 \mathrm{mg} / \mathrm{kg}$ dan $23,3974 \mathrm{mg} / \mathrm{kg}$.

Pemerintah Republik Indonesia melalui KepMen LH No. 51/MENLH/10/1995 dan PP No 82 tahun 2001 mengenai pengelolaan kualitas air dan pengendalian pencemaran air, mewajibkan pelaku industri yang dalam kegiatan produksinya menghasilkan limbah dalam jumlah besar dan berpotensi mencemari lingkungan harus melengkapi kegiatan industrinya dengan instalasi pengolahan air limbah yang memadai. Hal ini dilakukan pemerintah dalam rangka pengendalian pencemaran lingkungan oleh limbah industri

Remediasi logam berat di lingkungan dapat dilakukan dengan beberapa metode seperti kimia, fisika dan biologi. Metode fisika dan kimia telah terbukti efektif dalam mengelola limbah namun memiliki kekurangan, yaitu belum dapat sepenuhnya diaplikasikan pada industri kecil dan menengah sebab biaya yang diperlukan akan mahal ketika 
logam dalam larutan berada di kisaran 1-100 mg/L (Malik, 2004) serta biaya yang tinggi juga akan diperlukan untuk regenerasi resin atau mengaktifkan karbon (Magni et al., 2015).

Pendekatan secara bioteknologi dengan menggunakan mikroorganisme merupakan alternatif yang dapat dilakukan untuk mengolah logam berat.Proses biologi merupakan salah satu alternatif yang dapat digunakan untuk mengolah limbah logam berat yang terdapat di limbah cair. Keuntungan dari pengolahan limbah logam berat secara biologi, antara lain biaya proses serta pemeliharaan yang rendah (Pacini et al., 2005)

Banyaknya data yang menginformasikan bahwa perairan di Bali khususnya kawasan Denpasar Selatan telah banyak yang tercemar oleh logam berat, sehingga memungkinkan untuk memanfaatkan bakteri pengakumulasi logam berat di dalamnya sebagai agen bioremoval logam berat.

Dalam penelitian ini akan ditumbuhkan sedimen dari tiga perairan, yaitu pelabuhan Benoa, perairan mangrove Patung Ngurah Rai Tuban, dan Estuari Dam Suwung dalam media cair selektif untuk mendapatkan sumber sedimen terbaik yang dapat digunakan sebagai suspensi aktif untuk menurunkan konsentrasi $\mathrm{Pb}$ dan $\mathrm{Cr}$ terlarut. Sedimen terbaik akan ditentukan dengan peningkatan biomasa (VSS) dan kecepatan waktu pertumbuhan. Kemampuan biofiltrasi vertikal ditentukan dengan efektifitasnya dalam menurunkan kadar $\mathrm{Pb}$ dan $\mathrm{Cr}$ serta kapasitas sistem yang digunakan. Selain itu akan diidentifikasi pula bakteri yang berperan dalam proses pengolahan tersebut.

\section{METODOLOGI}

\subsection{Lokasi dan Waktu Penelitian}

Laboratorium Penelitian Jurusan Kimia FMIPA Universitas Udayana dan Laboratorium Mikrobiologi Jurusan Biologi FMIPA Universitas Udayana dilakukan selama 2 bulan.

\subsection{Bahan dan Alat Penelitian}

Sedimen Pelabuhan Benoa, perairan mangrove Patung Ngurah Rai Tuban, dan Estuari Dam Suwung, $\mathrm{Pb}\left(\mathrm{NO}_{3}\right)_{2}, \mathrm{~K}_{2} \mathrm{Cr}_{2} \mathrm{O}_{7}$, aquades, NPK, glukosa $(\mathrm{KH}), \mathrm{K}_{2} \mathrm{HPO}_{4},\left(\mathrm{NH}_{4}\right)_{2}\left[\mathrm{Fe}\left(\mathrm{SO}_{4}\right)_{2}\right] \cdot 6 \mathrm{H}_{2} \mathrm{O}, \mathrm{MgSO}_{4}$, $\mathrm{FeSO}_{4}$, dan ekstrak ragi. Erlenmeyer, gelas beker, pipet volume, labu ukur, cawan porselen, batang pengaduk, oven, tanur, pipet tetes, selang aerator, aerator, kapas, desikator, tabung biofilter dan AAS.

\subsection{Rancangan Percobaan}

Penelitian ini dirancang secara eksperimental. Digunakan tiga sedimen perairan berbeda untuk mendapatkan sumber sedimen terbaik yang dapat digunakan sebagai suspensi aktif untuk menurukan konsentrasi $\mathrm{Pb}$ dan $\mathrm{Cr}$ terlarut. Sedimen terbaik akan diaplikasi ke dalam biosistem untuk mengolah logam $\mathrm{Pb}$ dan $\mathrm{Cr}$ terlarut. Perubahan konsentrasi kedua logam ditinjau berdasar lama waktu pengolahan di dalam biosistem.

\subsection{Penentuan Sumber Data}

Sampel berupa sedimendiambil pada ekosistem Pelabuhan Benoa, perairan mangrove Patung Ngurah Rai Tuban Denpasar Selatan, dan Estuary Dam Suwung. Pengambilan sampel sedimen dilakukan melalui metode grab, yaitu dilakukan sekali pada saat pengambilan contoh dengan mengambil bagian dari suatu material yang mengandung mineral secara acak. Pengambilan sampel tanah masing-masing ekosistem diambil secara komposit yaitu diambil pertitik dari hulu ke hilir dengan asumsi dapat mewakili keseluruhan kawasan tempat pengambilan sampel.Sampel sedimen diambil dengan menggunakan sendok dengan kedalaman $10 \mathrm{~cm}$ dari permukaan dengan berat 2 gram pertitik lokasi pengambilan.

\subsection{Proses Pembibitan}

a. Diambil sampel berupa sedimen dari tigaperairan berbeda kemudian dimasukkan ke dalam 3 gelas beaker berbedauntuk proses pembibitan

b. Kemudian diberi aerasi pada masing - masing gelas beaker dilakukan dengan menggunakan aerator yang diberi selang kemudian diletakkan pada dasar gelas beaker.

c. Pengamatan dilakukan dengan mengukur nilai VSS (Volatile Suspended Solid) hingga mencapai harga $2000 \mathrm{mg} / \mathrm{L}$.

\subsection{Aklimitasi}

Tahap aklimitasi merupakan pengguanaan komposisi lumpur yang berisi bibit mikroorganisme hasil dari proses pembibitan untuk mengolah larutan logam $\mathrm{Pb}$ dan $\mathrm{Cr}$.

Prosedur aklimitasi antara lain: disiapkan empat buahtabung paralon dengan diameter $12 \mathrm{~cm}$ dan tinggi $50 \mathrm{~cm}$.Batuan vulkanik dimasukkan ke dalam masing-masing tabung. Bibit terbaik dimasukkan ke dalam tiga tabung paralon berbeda sebanyak $2 \mathrm{~L}$ bibit per tabung. Bibit ditumbuhkan hingga terbentuk biofilm pada permukaan 
batu.Kedalam masing-masing tabung dimasukkan $2 \mathrm{~L}$ larutan campuran $\mathrm{Pb}$ dan $\mathrm{Cr}$. Pengambilan sampel dilakukan setiap 6 jam hingga konsentrasi $\mathrm{Pb}$ dan $\mathrm{Cr}$ mencapai baku mutu.

\section{HASIL PENELITIAN}

\subsection{Pengaruh Sumber Sedimen Terhadap Pertumbuhan Biomassa Mikroba Yang Diukur Dengan Parameter Volatile Suspended Solid (VSS)}

Sedimen perairan yang digunakan antara lain, perairan mangrove Patung Ngurah Rai Tuban, pelabuhan Benoa dan Estuari Dam Suwung. Sebanyak 0,5 g masing-masing sedimen dibibit dalam $500 \mathrm{~mL}$ media cair. Pengambilan sampel untuk penentuan VSS dilakukan tiap 6 jam selama 2 hari.Pengukuran VSS dilakukan setelah lumpur dimasukan ke dalam tempat pembibitan, dengan sistem aerasi serta penambahan nutrien hara berupa 2 gram glukosa; 0,1 gram $\mathrm{K}_{2} \mathrm{HPO} 4$; 0,1 gram $\left(\mathrm{NH}_{4}\right)_{2}\left[\mathrm{Fe}\left(\mathrm{SO}_{4}\right)_{2}\right] \cdot 6 \mathrm{H}_{2} \mathrm{O} ; 0,02$ gram $\mathrm{MgSO}_{4} ; 0,02$ gram $\mathrm{FeSO}_{4} ; 0,02$ gram ekstrak ragi, 0,02 gram $\mathrm{Pb}\left(\mathrm{NO}_{3}\right)_{2}$, dan 0,02 gram $\mathrm{K}_{2} \mathrm{Cr}_{2} \mathrm{O}_{7}$,

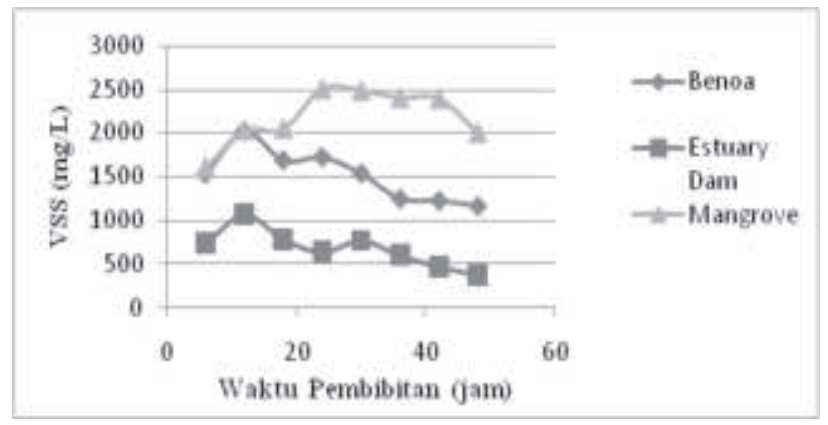

Gambar 1. Pengaruh Waktu Pembibitan Terhadap Kadar VSS (Pertumbuhan Mikroorganisme) Sedimen Pelabuhan Benoa, Estuari Dam Suwung, dan Mangrove, Dengan 0,5 gram Sedimen dan 500 $\mathrm{mL}$ Media Cair

Berdasarkan Gambar 1. dapat dilihat bahwa secara umum pengamatan pada jam ke 6 telah menunjukan adanya pertumbuhan biomassa dan meningkat hingga jam ke 12 . Nilai VSS dari sedimen Estuary Dam mencapai titik maksimum pada jam ke 12 dengan nilai VSS 1044,7 mg/L, nilai tersebut dibawah nilai fase akselerasi, yang artinya sedimen Estuary Dam tidak dapat digunakan sebagai sumber biomassa untuk mengolah $\mathrm{Pb}$ dan $\mathrm{Cr}$ sebab memiliki pertumbuhan yang kurang baik. Sedimen dari perairan Benoa dan Mangrove mencapai titik maksimum pada jam ke 12 dengan nilai VSS berturut-turut sebesar 2019,0 dan 2034,7 mg/L, nilai tersebut di atas $2000 \mathrm{mg} / \mathrm{L}$, yang artinya biomassa telah memasuki fase akselerasi sehingga mikroorganisme mampu melakukan aktivitas dalam menurunkan konsentrasi bahan organik maupun anorganik dalam lingkungan tercemar.

Dengan pertambahan waktu pembibitan, VSS dari sedimen perairan Benoa cenderung mengalami penurunan dengan nilai di bawah $2000 \mathrm{mg} / \mathrm{L}$. Sedangkan biomassa dari perairan Mangrove dengan pertambahan waktu pembibitan mengalami penurunan nilai VSS pula, tetapi dengan nilai yang masih di atas $2000 \mathrm{mg} / \mathrm{L}$. Hal ini menunjukkan bahwa sedimen dari perairan Mangrove lebih banyak mengandung mikroorganisme yang toleran dan mampu bertahan terhadap paparan $\mathrm{Pb}$ dan $\mathrm{Cr}$ dibandingkan dengan dua ekosistem lainnya. Dengan demikian, biomassa yang akan digunakan dalam biosistem untuk mengolah $\mathrm{Pb}$ dan $\mathrm{Cr}$ adalah biomassa hasil pembibitan dari sedimen Mangrove. Dengan demikian, biomassa yang akan digunakan dalam sistem biofiltrasi untuk mengolah $\mathrm{Pb}$ dan $\mathrm{Cr}$ adalah biomassa hasil pembibitan dari sedimen Mangrove.

\subsection{Penentuan Kemampuan Bioreaktor Dalam Mengakumulasi Logam Berat}

Pada tahapan ini digunakan 2 jenis biofiltrasi, yaitu biofiltrasi kontrol dan biofiltrasi inokulum bakteri. Biofiltrasi kontrol hanya berisi batu sebagai agen pengolah, sedangkan biofiltrasi inokulumbakteri menggunakan agen pengolah berupa suspensi aktif yang berasal dari sedimen Mangrove yang telah dibibit dengan menggunakan batu sebagai media pertumbuhan. Baik biofiltrasi kontrol maupun biofiltrasi inokulum mikroorganisme menggunakan batu dengan jenis dan jumlah yang sama.

\subsubsection{Konsentrasi Pb Selama Pengolahan Dengan Biofiltrasi Kontrol Dan Biofiltrasi Inokulum Bakteri}

Konsentrasi $\mathrm{Pb}$ dalam limbah setelah pengolahan dengan biosistem kontrol mengalami penurunan dibandingkan dengan konsentrasi awal. Penurunan tertinggi terjadi saat waktu pengolahan ke 6 jam, yaitu dari konsentrasi awal sebesar 1,9470 ppm menjadi 1,2030 ppm. Sedangkan pada waktu pengolahan selanjutnya kosentrasi sisa $\mathrm{Pb}$ dalam larutan semakin meningkat seiring dengan pertambahan waktu pengolahan.

Tabel 1. Konsentrasi Logam Pb Dalam Larutan Pada Tiap Waktu Pengolahan Dengan Biofiltrasi Kontrol

\begin{tabular}{cc}
\hline Waktu Pengolahan (jam) & Konsentrasi (ppm) \\
\hline 0 & 1,9470 \\
6 & 1,2030 \\
12 & 1,2820 \\
18 & 1,3130 \\
24 & 1,6400 \\
\hline
\end{tabular}


Penurunan konsentrasi $\mathrm{Pb}$ dalam larutan saat pengolahan dengan biofiltrasi kontrol terjadi dimungkinkan karena logam $\mathrm{Pb}$ teradsorpsi pada permukaan batu. Selain itu, dimungkinkan terdapat bakteri yang terdapat di dalam batu yang memiliki kemampuan untuk mengikat logam. Kenaikan konsentrasi sisa $\mathrm{Pb}$ dalam larutan setelah waktu pengolahan ke 6 jam kemungkinan terjadi karena logam yang terserap pada permukaan batu terikat secara lemah (adsorpsi fisika), sehingga memungkinkan untuk terlepas kembali ke fase air seiring dengan kenaikan waktu kontak.

Tabel 2. Konsentrasi Pb Pada Tiap Waktu Pengolahan Dengan Biofiltrasi Inokulum Bakteri

\begin{tabular}{cc}
\hline Waktu Pengolahan (jam) & Konsentrasi (ppm) \\
\hline 0 & 1,9470 \\
6 & 0,1680 \\
12 & 0,0900 \\
18 & 0,0340 \\
24 & 0,0100 \\
48 & 0,0150 \\
72 & 0,0310 \\
96 & 0,0340 \\
120 & 0.1580 \\
\hline
\end{tabular}

Konsentrasi $\mathrm{Pb}$ dalam larutan simulasi setelah pengolahan dengan biofiltrasi inokulum bakteri mengalami penurunan seiring dengan naiknya waktu pengolahan. Penurunan tertinggi terjadi pada waktu pengolahan ke 24 jam saat konsentrasi $\mathrm{Pb}$ yang tersisa dalam larutan sebesar $0,010 \mathrm{ppm}$. Nilai tersebut telah berada di bawah baku mutu $\mathrm{Pb}$ yang diijinkan dalam air sesuai dengan PerGub Bali No. 8 Tahun 2007, yaitu sebesar 0,03 ppm.

Berdasarkan hasil yang diperoleh, konsentrasi $\mathrm{Pb}$ dalam larutan mengalami penurunan yang signifikan saat pengolahan dengan biofiltrasi inokulum bakteri dibandingkan dengan biofiltrasi kontrol. Hal ini sesuai dengan teori yang mengatakan bahwa beberapa jenis bakteri memiliki kemampuan untuk menurunkan konsentrasi $\mathrm{Pb}$ dalam larutan. Adapun beberapa proses yang dilakukan bakteri untuk menurunkan konsentrasi $\mathrm{Pb}$ dalam larutan (Naik and Dubey, 2013), antara lain:

1. Mengakumulasi Pb di dalam sel.

2. Menahan $\mathrm{Pb}$ pada permukaan sel.

3. Menahan pada permukaan bakteri.

4. Membentuk presipitat.

Peningkatan konsentrasi logam $\mathrm{Pb}$ setelah mengalami penurunan saat proses pengolahan dimungkinkan karena:

1. Proses transporaktif yang melibatkan ATP.

2. Logam yang terserap pada permukaan batu terikat secara lemah (adsorpsi fisika), sehingga memungkinkan untuk terlepas kembali ke fase air.

\subsubsection{Konsentrasi Cr Selama Pengolahan Dengan Biofiltrasi Kontrol Dan Biofiltrasi Inokulum Bakteri}

Konsentrasi logam Cr dalam larutan simulasi dibuat dengan konsentrasi 2 ppm, pada AAS terukur sebesar 2,0468 ppm. Larutan tersebut digunakan sebagai sampel untuk diolah dalam biofiltrasi kontrol dan biofiltrasi inokulum bakteri. Variasi waktu pengolahan diteliti untuk mendapatkan waktu pengolahan optimal, yaitu waktu disaat terjadi penyerapan konsentrasi logam $\mathrm{Cr}$ tertinggi.

Tabel 3. Konsentrasi Logam Cr Dalam Larutan Pada Tiap Waktu Pengolahan Dengan Biofiltrasi Kontrol

\begin{tabular}{cc}
\hline Waktu Perlakuan Sampel (jam) & Konsentrasi (ppm) \\
\hline 0 & 2,0468 \\
6 & 1,9140 \\
12 & 1,8540 \\
18 & 1,9570 \\
24 & 1,9230 \\
\hline
\end{tabular}

Konsentrasi $\mathrm{Cr}$ dalam larutan setelah pengolahan dengan biofiltrasi kontrol mengalami penurunan dibandingkan dengan konsentrasi awal. Penurunan tertinggi terjadi pada waktu pengolahan ke 12 jam, yaitu dari konsentrasi awal sebesar 2,0468 ppm menjadi 1,8540 ppm. Sedangkan pada waktu pengolahan selanjutnya konsentrasi sisa $\mathrm{Cr}$ dalam larutan semakin meningkat seiring dengan pertambahan waktu pengolahan.

Penurunan kosentrasi Cr terjadi dimungkinkan karena logam Cr teradsorpsi pada permukaan batu. Selain itu, dimungkinkan terdapat bakteri yang terdapat di dalam batu yang memiliki kemampuan untuk mengikat logam. Kenaikan kosentrasi logam Cr dalam larutan setelah waktu pengolahan ke 12 jam kemungkinan terjadi akibat logam yang terserap pada permukaan batu terikat secara lemah (adsorpsi fisika), sehingga memungkinkan untuk terlepas kembali ke fase air

Konsentrasi $\mathrm{Cr}$ dalam larutan setelah pengolahan dengan biofiltrasi inokulum bakteri. Konsentrasi $\mathrm{Cr}$ mengalami penurunan seiring dengan naiknya waktu pengolahan. Penurunan tertinggi terjadi pada waktu pengolahan ke 24 jam disaat konsentrasi $\mathrm{Cr}$ yang masih tersisa dalam limbah sebesar 0,0120 ppm. Nilai tersebut telah berada di bawah baku mutu Cr yang diijinkan dalam airsesuai dengan PerGub Bali No. 8 Tahun 2007.

Konsentrasi $\mathrm{Cr}$ dalam larutan mengalami penurunan yang signifikan saat pengolahan dengan biofiltrasi inokulum bakteri dibandingkan dengan biofiltrasi kontrol. Hal ini sesuai dengan teori yang mengatakan bahwa terdapat beberapa jenis bakteri memiliki kemampuan untuk menurunkan konsentrasi Cr dalam larutan. Adapun beberapa proses yang dilakukan bakteri untuk menurunkan 
konsentrasi dan toksisitas Cr dalam larutan (Gadd, 1990), antara lain :

1. Mengakumulasi logam $\mathrm{Cr}$ dalam sel.

2. Mengikat $\mathrm{Cr}$ pada dinding sel.

Meningkatnya kembali konsentrasi logam $\mathrm{Cr}$ dalam limbah setelah adanya penurunan dapat terjadi karena beberapa kemungkinan, yaitu:

1. Jumlah bakteri di dalam biosistem menurun (Soeparno, 1992).

2. Akibat $\mathrm{Cr}$ yang masuk ke dalam sel bakteri terlalu banyak, sehingga $\mathrm{Cr}$ akan dikeluarkan kembali dari sel bakteri (Gadd, 1990).

Tabel 4. Konsentrasi Cr Pada Tiap Waktu Pengolahan Dengan Biofiltrasi Inokulum Bakteri

\begin{tabular}{cc}
\hline Waktu Perlakuan Sampel (jam) & Konsentrasi (ppm) \\
\hline 0 & 2,0468 \\
6 & 0,1460 \\
12 & 0,0620 \\
18 & 0,0230 \\
24 & 0,0120 \\
48 & 0,0200 \\
72 & 0,0360 \\
96 & 0,0480 \\
120 & 0,0660 \\
144 & 0,1580 \\
\hline
\end{tabular}

3.3 Efektivitas Dan KapasitasBiofiltrasi dalam Menurunkan Konsentrasi Logam $\mathrm{Pb}$ Dan Cr Terlarut

Efektivitas biofiltrasi dalam menyerap logam $\mathrm{Pb}$ dan $\mathrm{Cr}$ pada setiap proses pengolahan dapat ditentukan dengan membandingkan selisih konsentrasi awal dan akhir $\mathrm{Pb}$ atau $\mathrm{Cr}$ dalam larutan dengan konsentrasi awal $\mathrm{Pb}$ atau $\mathrm{Cr}$ dalam larutan.

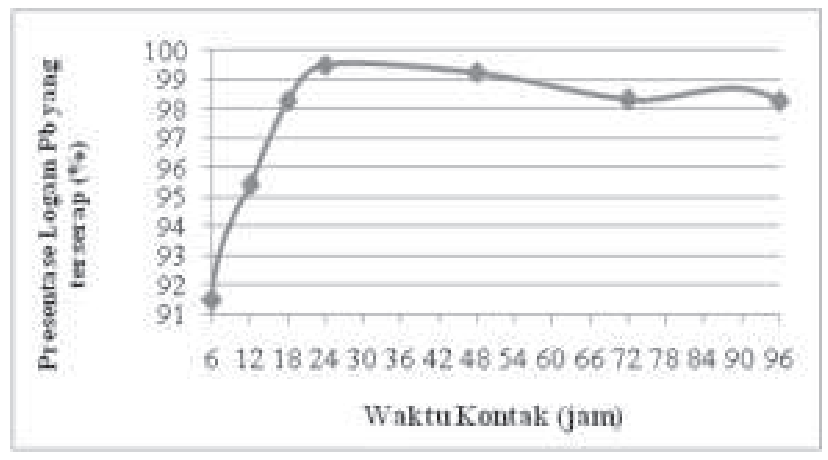

Gambar 2. Grafik Efektivitas Biosistem Dalam Menurunkan Konsentrasi $\mathrm{Pb}$ Terlarut
Berdasarkan kurva pada Gambar 2 dan 3 terlihat bahwa biofiltrasi inokulum bakteri efektif menurunkan konsentrasi logam baik $\mathrm{Pb}$ maupun $\mathrm{Cr}$ mulai dari waktu pengolahan ke 6 hingga 96 jam. Hal ini ditunjukkan dengan nilai efektivitas biofiltrasi inokulum bakteri berada di atas nilai $50 \%$ saat waktu pengolahan tersebut, yaitu untuk logam $\mathrm{Pb}$ berturut-turut sebesar $91,44 \%$ dan $98,25 \%$, sedangkan untuk logam $\mathrm{Cr}$ sebesar $92,85 \%$ dan $97,66 \%$. Nilai efektivitas tertinggi untuk $\mathrm{Pb}$ dan $\mathrm{Cr}$ terjadi saat waktu pengolahan ke 24 jam, yaitu sebesar $99,49 \%$ dan $99,41 \%$.

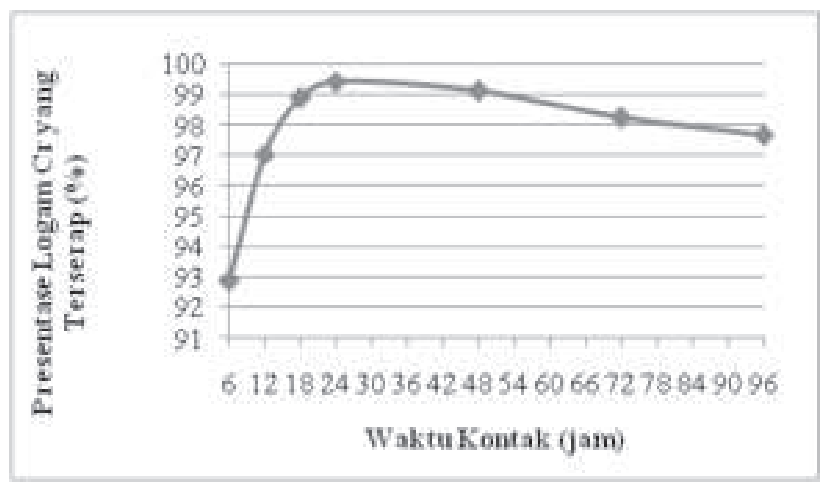

Gambar 3. Grafik Efektivitas Biosistem Dalam Menurunkan Konsentrasi CrTerlarut

Kapasitas biofiltrasi inokulum bakteri sedimen mangrove dalam menurunkan konsentrasi logam $\mathrm{Pb}$ pada saat waktu optimal sebesar $4,3188 \times 10^{-3} \mathrm{mg} / \mathrm{g}$ dan

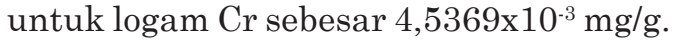

\subsection{Identifikasi Bakteri}

Bakteri yang diidentifikasi antara lainColiform, Pseudomonas sp., Bacillus sp. danE.Coli. Berdasarkan hasil uji identifikasi didapatkan data jumlah masing-masing bakteri dan jumlah total mikroorganisme yang dilampirkan dalam Tabel 1.Diketahui bahwa bakteri yang terdapat pada biofiltrasi adalah Bacillus sp. Hal ini sesuai dengan literatur yang mengatakan bahwa bakteri Bacillus $s p$. sangat toleran terhadap toksisitas logam berat, serta memilki kemampuan tinggi untuk menyerap logam berat (Beveridgeand Murray, 1980).

Bakteri Bacillus spdigolongkan ke dalam bakteri sel berbentuk batang mempunyai ukuran 0,3-2,2 ìm x 1,27-7,0 ìm, gram positif, aerobik dan anaerobik fakultatif, serta umumnya dijumpai di tanah (Waluyo, 201). 
Tabel 5. Hasil Identifikasi Biofilm Pada Permukaan Batu

\begin{tabular}{cccccc}
\hline Kode Sampel & ALT (CFU/gr) & Coliform (MPN/100 gr) & E. coli(MPN/100 gr) & Bacillus sp. (CFU/gr) & Pseudomonas sp. (CFU/gr) \\
\hline A & 320 & 0 & 0 & 20 & 0 \\
B & 180 & 0 & 0 & 10 & 0 \\
\hline
\end{tabular}

Sumber : Laboratorium Mikrobiologi Jurusan Biologi FMIPA UNUD

\section{KESIMPULAN DAN SARAN}

\subsection{Kesimpulan} yaitu :

Pada hasil penelitian diatas dapat disimpulkan

1. Sumber sedimen terbaik adalah yang berasal dari ekosistem perairan Mangrove Patung Ngurah Rai Tuban, dengan nilai VSS sebesar $2034.7 \mathrm{mg} / \mathrm{L}$ dalam waktu 12 jam pembibitan. Nilai tersebut lebih besar dibandingakan dengan nilai VSS ekosistem Benoa dan Estuari Dam Suwung yang hanya $2019.0 \mathrm{mg} / \mathrm{L}$ dan 1044.7 $\mathrm{mg} / \mathrm{L}$ pada waktu 12 jam pembibitan.

2. Waktu optimal pengolahan sistem biofiltrasi yang ditambahkan suspensi aktif terbaik adalah 24 jam dengan efektivitas dan kapasitas untuk $\mathrm{Pb}$ sebesar $99,49 \%$ dan $4,2653 \times 10^{-3} \mathrm{mg} / \mathrm{g}$ serta untuk Cr sebesar 99,41\% dan $4,4566 \times 10^{-3} \mathrm{mg} / \mathrm{g}$.

3. Bakteri yang berperan dalam menurunkan konsentrasi logam $\mathrm{Pb}$ dan $\mathrm{Cr}$ terlarut salah satunya teridentifikasi sebagai Bacillus sp. dengan jumlah $20 \mathrm{CFU/gr.}$

\subsection{Saran}

1. Perlu adanya pengamatan pada kurva penurunan konsentrasi logam $\mathrm{Pb}$ dan $\mathrm{Cr}$ sebelum waktu pengolahan ke 6 jam.

2. Perlu adanya penelitian untuk meregenerasi biofiltrasi dalam mengolah logam $\mathrm{Pb}$ dan $\mathrm{Cr}$.

\section{DAFTAR PUSTAKA}

Beveridge, T.J. and Murray, R.G., 1980, Sites of Metal Deposition in The Cell Wall of Bacillus subtilis, Journal Bacteriol, 141: 876-887

Bogoriani, N.W., 2007, Penetapan kadar pencemaran logam $\mathrm{Pb}$ dan $\mathrm{Cr}$ pada ikan nila (Oreochromis Niloticus) di Muara Sungai Badung, Ecotrophic Journal of Environmental Sciences, 2: 1-7

Dewi, N.L., Emmy, S., dan Laksmiwati, 2014, Fraksinasi dan Bioavailabilitas Logam $\mathrm{Pb}$ dan Cr dalam Sedimen Pelabuhan Benoa, Jurnal Kimia, 8(1): 63-69

Gadd, G.M., 1990, Metal tolerance, Mcgraw-Hill, New York

Garcia, R., Juan C., Julio A. C., Elena C., Elena R., and German B., 2016, Biosorption of Cd, Cr, Mn, and $\mathrm{Pb}$ from Aqueous Solutions by Bacillus sp. Strains Isolated from Industrial Waste Activate Sludge, TIP Revista Especializada en Ciencias Químico-Biológicas,19:5-1

Hegazi, H.A., 2013, Removal of heavy metals from wastewater using agricultural and industrial wastes as adsorbents, Housing and Building National Research Center, 3: 276-282

Magni, S., Parolini, M., Soave, C., Marazzi, F., Mezzanotte, V., and Binelli, A., 2015, Removal 
of metallic elements from real wastewater using zebra mussel bio-filtration process, Journal of Environmental Chemical Engineering, 3: 915921

Malik, A., 2004, Metal Bioremediation by Growing Cells, Environment International, 30: 261-278

Naik, M.M. and Dubey, S.H., 2013, Lead Resistant Bacteria: Lead Resistance Mechanisms, their Applications in Lead Bioremediation and Biomonitoring, Ecotoxixology and Environmental Safety, 98: 1-7

Pacini, V.A., Ingallinela, A.M., and G. Sanguinetti, 2005, Removal of iron and manganese using biological roughing up flow filtration, Water Research, 39: 4463-4475
Soeparno, 1992, Ilmu Dan Teknologi Daging, Penerbit Gajah Mada Press,Yogyakarta

Sudaryati, L. G., Kasa, I.W., dan Suyasa, I.W.B., 2011, Pemanfaatan Sedimen Perairan Tercemar Sebagai Bahan Lumpur Aktif Dalam Pengolahan Limbah Cair Industri Tahu, Ecotrophic, 3 (1): $21-29$.

Suriani, N.L., 2007, Kualitas air mangrove ditinjau dari sifat fisik-kimia hutan mangrove patung Ngurah Rai Tuban Denpasar Selatan Bali, Ecotrophic Journal of Environmental Sciences, 3: 7-9

Suyasa, B. and Wahyu, D., 2015, Biosystem treatment approach for seaweed processing wastewater, Journal of Environment and Waste Management, 2(2): 059-062. 